\title{
Tn Antigen Antibody
}

National Cancer Institute

\section{Source}

National Cancer Institute. In Antigen Antibody. NCI Thesaurus. Code C120487.

Any immunog lobulin that recognizes $\mathrm{T} n$ antigen, which is comprised of $\mathrm{N}$ -

acetylgalactosamine (GalNAc) bound to serine or threonine protein residues by O-linked glycosylation. 